\title{
AGRITOURISM IN THE CONTEXT OF SUSTAINABLE TOURISM DEVELOPMENT
}

\author{
Diana Foris ${ }^{1}$, Dr. Eng, Associate Professor; Baiba Rivza ${ }^{2}$, Dr.habil. Oec., Professor; Maiga \\ Kruzmetra ${ }^{3}$, Senior researcher; Ioana Sonia Comanescu ${ }^{4}$, Dr. Eng, Associate Professor; \\ Tiberiu Foris ${ }^{5}$, Dr. Oec, Professor \\ ${ }_{1,4}$ Transilvania University of Brasov, Romania; 2,3 Latvia University of Life Sciences and Technologies, Latvia; \\ ${ }^{5}$ Transilvania University of Brasov, Romania
}

\begin{abstract}
Between agritourism and sustainable development there is a close link. Agritourism acts as an integrator for local development and preservation of traditions and historical heritage, as well as for other economic sectors: agriculture, transport, services etc. This research presents an analysis of the evolution of the agritourism infrastructure and of the main tourism indicators for Romania as a tourist destination, as part of the development of the tourism industry. Quantitative and comparative analyses were carried out regarding the number and the existing accommodation capacity for agro-tourist boarding houses and the numerical evolution for domestic and international arrivals related to agritourism throughout the period between 2009 and 2017. Romania is an important agritourism destination, well known at national and international level for its unaltered natural resources (wild landscapes and nature) and preservation of traditions in rural area. A better understanding of processes occurring in the country could be achieved by comparing the processes with similar ones in another European Union Member State, which, in the present research, is Latvia, thereby confirming the cooperation of scientists of both countries in doing research on the viability of rural areas.
\end{abstract}

Key words: agritourism, sustainable development, rural areas

JEL code: O18, Q56, Z31, Z32

\section{Introduction}

Agritourism is directly linked to agricultural activities, being practiced by small farmers and these activities carried out in their own household are the main source of income (Foris D, et al., 2018). There are also other concepts such as "farm tourism", "green tourism" that have the same content. In European Union, rural tourism is a concept that includes tourist activity organized and led by the local population, based on a close connection with the natural and human environment (Caratus Stanciu M., 2017). Agri-tourism is one of the most dynamic forms of tourism in the European Union, due to the current trend of returning to origins and, also due to the advantages that it offers to both tourists and the host communities. Rural areas are rich in ecological and rural diversity (Dorobantu M. R., et al., 2012), to which the tourism resources (natural, cultural and human) and the tourism facilities and equipment, including tourist guests houses and agro-touristic farms as well are added (Nistoreanu P., 2007).

In Romania, the current legislation has defined agro-tourist boarding houses as establishments of tourist reception, with a capacity of accommodation of up to 8 rooms, operating in citizens' homes or in an independent building, which ensures in specially arranged spaces the tourists' accommodation and the conditions for preparing and serving the meal, as well as the possibility to participate at household or craft activities. In agri-tourist boarding houses, tourists are offered the meal prepared from mostly natural products from their own household (including fish products) or from locally authorized producers / fishermen. The hosts deal directly with the reception of tourists and their program throughout the stay at the pension and will accompany tourists who participate in traditional, household or crafts activities. Within the agri-tourist boarding houses, there is at least one activity related to agriculture, fish farming, fisheries, reed harvesting, animal husbandry,

\footnotetext{
${ }^{1}$ Diana Foris e-mail: diana.foris@unitbv.ro

2 Baiba Rivza e-mail: baiba.rivza@llu.lv

3 Maiga Kruzmetra e-mail: maiga.kuzmetra@llu.Iv

${ }^{4}$ Ioana Sonia Comanescu e-mail: ioanacom@unitbv.ro

5 Tiberiu Foris e-mail: tiberiu.foris@unitbv.ro
} 
cultivation of different types of plants, orchards or fruit trees or a craft activity, with a workshop, from which different handicraft products results. The activities in question must be carried out continuously or depending on the specificity and seasonality, in order to have repeatability (Order no. 65, Annex 1.5, 2013). An example would be grape processing in wine-growing areas, considering the fact that wine regions offers many tourist land marks with high quality wines: places with interesting architecture, historical castles, cultural festivities, amazing landscapes, etc. (Canja C. M., 2010), and the emotional connection between wine, identity and region image is a key event for international and domestic tourism.

The exceptional tourism potential of Romania has two main components: the natural component, represented by spectacular landscapes, varied configuration of the relief, favourable climatic conditions and lots of natural therapeutic spas; and the historical component, represented by traces of succeeding civilisations that had lived on Romanian territory since ancient times, monuments and lay or religious art objects, museums and museum collections, beautiful and original ethnographical and folklore elements and actual prestigious achievements (Sumovoschi C. D., et al., 2015).

If in the beginning, in Romania, agri-tourism was practiced by the peasants who had additional accommodation in their houses, now agri-tourism is more and more an activity carried out in buildings built in accordance with the legal requirements regarding comfort, but keeping the local specific, being an activity developed both by the locals and by the people who moved to the country. Thus, this form of tourism has undergone constant development and has become a way of achieving sustainable development of rural areas. Romania is actually following the successful models developed in Western Europe, where agri-tourism occupies a leading position in the tourists' preferences (National Institute of Statistics, 2017), because it is among the countries with a great agri-tourism potential, especially due to the wild landscapes and nature, to which contemporary people now want to return, but also because of the preservation of traditions, which have been preserved authentic over the centuries.

The objective of the research is to demonstrate that agritourism in Romania has undergone a continuous development process between 2009 and 2017, in order to confirm the viability of rural areas. In order to achieve this goal, the tasks of the present research are to demonstrate that the numerical evolution of agro-tourism boarding houses and the tourist accommodation capacity is increasing, that agri-tourism activities are sustainable and that agri-tourism plays a role of great importance within the country's tourism industry. In this respect, an analysis of the evolution of the agritourism infrastructure and of the main tourism indicators for Romania will be made. In order to a better understanding of the processes taking place in Romania, the analysis will be carried out by comparing the processes with similar ones in Latvia.

In Latvia, agritourism as well as cultural heritage as a way of supporting and expanding tourism in rural areas are among the research priorities (Liscova A., 2011; Jeroscenkova L., 2016). The cooperation of both countries in doing research on tourism in rural areas has already been established (Kruzmetra M. et al., 2018), which is expanded and continues in the form of the present paper.

\section{Materials and Methods}

The analysis was carried out on the basis of the statistical data provided by the National Institute of Statistics published in the Romanian Tourism Statistical Abstract for the period between 2009 and 2017. Quantitative and comparative analyses were carried out regarding the total number and the existing accommodation capacity for agro-tourist boarding houses and the numerical evolution for 
domestic arrivals and international arrivals throughout the period between 2009 and 2017. Data on agritourism in Latvia for the same period were acquired from the Statistical Bureau of Latvia (CSBL).

\section{Research results and discussion}

We started by analysing the numerical evolution for agro-tourist boarding houses in Romania and Latvia in Table 1.

Table 1

The numerical evolution of agro-tourist boarding houses

\begin{tabular}{|l|c|c|c|c|c|c|c|c|c|c|}
\hline No & Year & $\mathbf{2 0 0 9}$ & $\mathbf{2 0 1 0}$ & $\mathbf{2 0 1 1}$ & $\mathbf{2 0 1 2}$ & $\mathbf{2 0 1 3}$ & $\mathbf{2 0 1 4}$ & $\mathbf{2 0 1 5}$ & $\mathbf{2 0 1 6}$ & $\mathbf{2 0 1 7}$ \\
\hline 1. & Romania & 1412 & 1354 & 1210 & 1569 & 1598 & 1665 & 1918 & 2028 & 2556 \\
\hline 2. & Latvia & 327 & 375 & 390 & 385 & 307 & 306 & 257 & 291 & 467 \\
\hline
\end{tabular}

Source: author's calculations based on The National Statistics Institute, Tourism of Romania - statistical summary 2009 - 2018; CSB of Latvia 2009 - 2017

In Romania, during the analysed period, we find a steady increase of number of agro-tourist boarding houses. There can be noticed a small decrease in 2011 for agro-tourist boarding houses, which can be attributed to the global economic crisis. Also, in 2012, there can be noticed a significant increase for agri-tourist boarding houses, a situation that may be caused by the good functioning of the National Rural Development Programme of Romania 2007-2013 (PNDR, 2012). Starting with 2012 , there is a constant increase of the number of these establishments. The effects of the global economic crisis were observed also in Latvia, two years later than in Romania. However, despite the slowdown in growth caused by the global economic crisis, the number of boarding houses for agrotourists rose in both countries in the analysis period. Besides, this process was much faster in Romania than in Latvia (181.01\% in Romania; $142.8 \%$ in Latvia).

Table 2

The tourist accommodation capacity for agro-tourist boarding houses

\begin{tabular}{|l|l|c|c|c|c|c|c|c|c|c|}
\hline No & Year & $\mathbf{2 0 0 9}$ & $\mathbf{2 0 1 0}$ & $\mathbf{2 0 1 1}$ & $\mathbf{2 0 1 2}$ & $\mathbf{2 0 1 3}$ & $\mathbf{2 0 1 4}$ & $\mathbf{2 0 1 5}$ & $\mathbf{2 0 1 6}$ & $\mathbf{2 0 1 7}$ \\
\hline 1. & Romania & 19783 & 20208 & 20683 & 27453 & 28775 & 30480 & 35188 & 37394 & 44409 \\
\hline 2. & Latvia & 12113 & 12717 & 14197 & 15134 & 11131 & 11460 & 10311 & 12177 & 15479 \\
\hline
\end{tabular}

Source: author's calculations based on The National Statistics Institute, Tourism of Romania - statistical summary 2009 - 2018; CSB of Latvia 2009 - 2017

Analysing the tourist accommodation capacity for the studied period in Table 2, we notice a significant increase regarding agro-tourist boarding houses in Romania (224.48\%).

It is necessary to mention that the increase of the units can be based on the fact that in 2016, started the National Rural Development Programme of Romania (2014-2017). The main objective of these activities is to contribute to sustainable economic development, to create jobs and to reduce poverty in rural areas (PNDR, 2017).

The tourist accommodation capacity for the studied period increased also in Latvia (127.8\%), yet the increase rate was lower than that in Romania. It could be explained by the fact that Latvia, in terms of area, is a small country compared with Romania, and one-day tourism was specific to Latvia. For example, one-day visitors totalled 960722 in Latvia in 2017. (Tourism in..., 2018).

In the following study, we will try to identify if the agro-tourism activities are sustainable, through the analysis of the demand for this type of tourism. In this regard, we will analyse in Fig. 1 the number of arrivals during the period 2009 -2017 for agri-tourist boarding houses. 


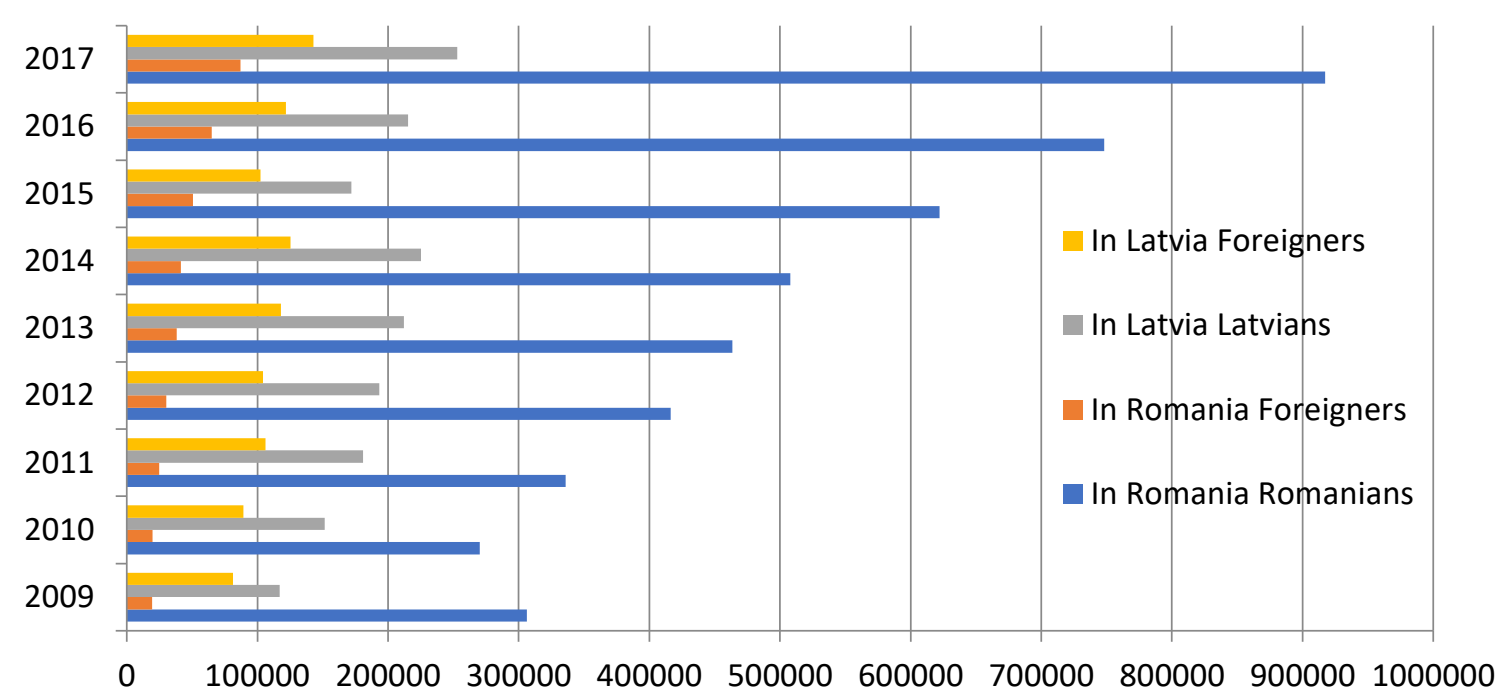

Source: author's calculations based on The National Statistics Institute, Tourism of Romania - statistical summary 2009 - 2018; CSB of Latvia 2009 - 2017

\section{Fig. 1. Tourists' arrivals in agri-tourist boarding houses}

Analysing the tourists' arrivals in agro-tourist boarding houses, we notice a significant increase, except for the period 2009-2010, when there is a small decrease in the number of tourists, both Romanian and foreign, as a result of the effects of the economic crisis. After 2011, there have been steady increases in the flow of arrivals for both the domestic and the international tourism flows but a slow evolution of the number of international arrivals. We can explain the slower evolution of the number of international arrivals, by identifying the negative aspects related to infrastructure, transport and promotion. Regarding the infrastructure, in many rural localities a drainage network and centralized water supply system are lacking. One of the main negative aspects of transport is the lack of highways and the existence of incomplete trans-European roads. In addition, we can take into account the fact that many rural tourist areas do not have an airport nearby, the stations and the coaches have inadequate equipment, the speed of trains does not correspond to the demands of the tourists nowadays, the lack of bus schedule, poor road quality. Regarding the promotion, one of the main problems is the lack of destination marketing organizations in rural areas and the lack of a coordinated network of tourist information centres.

In Latvia too, first of all, domestic tourists visit the nicest and most interesting sites in rural areas, which both give them cultural and historical knowledge and acquaint them to the cultural and historical heritage. It is not correct to compare the numbers of such tourists between Latvia and Romania, as the population of Romania is ten-fold larger than that of Latvia. The interest of foreign tourists in the nature of Latvia and the cultural environment outside the country's cities also increases.

The relative data, however, reveal a significant distinction: in Romania, the number of foreign agritourists increased faster than that of domestic agritourists. The situation in Latvia was opposite - the number of domestic agritourists rose faster than that of foreign agritourists in the analysed period. The rise in the number of domestic agritourists might be explained by the coming 100 th anniversary of Latvia's independence and the wish of the tourists to get better familiarised with their own country.

Agri-tourism plays an important role in sustainable development, but the question is whether agri-tourism plays an important role in the tourism industry of the respective country. In order to 
answer such a question, we will carry out an analysis to determine the contribution (in percentage) of the number and the accommodation capacity of the agri-tourism pensions in the total number and the accommodation capacity of the accommodation units in Romania and Latvia.

In Table 3 we represented the numerical evolution of the establishments of tourist reception with functions of accommodation in Romania and Latvia. In Romania we notice that in 2009 the total number of registered units was 5095, of which 1412 were represented by agri-tourist boarding houses. In 2017, the total number of units was 7905, of which 2556 were agro-tourist boarding houses, namely $32.33 \%$ of the total number of units and compared to 2009 , their number increased, the results following a positive trend.

The same processes were observed in Latvia too - the total number of tourist accommodation establishments rose, and the number of those located in rural areas rose as well. However, in terms of increase rate, Romania outpaced Latvia.

The numerical evolution of the establishments of tourist reception with functions of accommodation and the number of agro-tourist boarding houses

\begin{tabular}{|l|c|c|c|c|c|}
\hline No & $\begin{array}{c}\text { Annual } \\
\text { comparative } \\
\text { growth }\end{array}$ & $\begin{array}{c}\text { Establishments } \\
\text { of tourists } \\
\text { reception with } \\
\text { functions of } \\
\text { tourists } \\
\text { accommodation }\end{array}$ & $\begin{array}{c}\text { No. of agro- } \\
\text { tourist } \\
\text { boarding } \\
\text { houses }\end{array}$ & $\begin{array}{c}\text { Establishments } \\
\text { of tourists } \\
\text { reception with } \\
\text { functions of } \\
\text { tourists } \\
\text { accommodation }\end{array}$ & $\begin{array}{c}\text { No. of agro- } \\
\text { tourist } \\
\text { boarding } \\
\text { houses }\end{array}$ \\
\hline 1. & Year & \multicolumn{2}{|c|}{ Romania } & \multicolumn{2}{|c|}{ Latvia } \\
\hline 2. & 2009 & 5095 & 1412 & 559 & 327 \\
\hline 3. & 2010 & 5222 & 1354 & 628 & 375 \\
\hline 4. & 2011 & 5003 & 1210 & 641 & 390 \\
\hline 5. & 2012 & 5821 & 1569 & 632 & 385 \\
\hline 6. & 2013 & 6009 & 1598 & 546 & 307 \\
\hline 7. & 2014 & 6130 & 1665 & 544 & 306 \\
\hline $\mathbf{8 .}$ & 2015 & 6821 & 1918 & 563 & 257 \\
\hline 9. & 2016 & 6946 & 2028 & 607 & 291 \\
\hline 10. & 2017 & 7905 & 2556 & 809 & 487 \\
\hline 11. & Increase & $\mathbf{1 3 6 . 3} \%$ & $\mathbf{1 4 3 . 6} \%$ & $\mathbf{1 4 4 . 7} \%$ & $\mathbf{1 4 8 . 9} \%$ \\
\hline
\end{tabular}

Source: author's calculations based on The National Statistics Institute, Tourism of Romania - statistical summary 2009 - 2018; CSB of Latvia 2009 - 2017

A distinctive feature of Latvia was that the proportion of agro-tourist boarding houses in the total of tourist accommodation establishments increased at a faster rate $(7.3 \%$ percentage points in Romania; $4.2 \%$ percentage points in Latvia).

In Romania, in most cases hotels, hostels, bungalows etc. are located in or near urban areas, and at present, rural areas in Romania cover $87.1 \%$ (Management Authority for PNDR, 2013) of the country's territory, so there are perspectives for more favourable to the development of agrotourism.

The values for the total accommodation capacity for existing establishments of tourist reception with functions of accommodation in Romania and Latvia are also highlighted in the Table 4. 
Total accommodation capacity for establishments of tourist reception with functions of tourist accommodation and accommodation capacity for agritourist boarding houses

\begin{tabular}{|c|c|c|c|c|c|c|c|}
\hline No & $\begin{array}{l}\text { Annual } \\
\text { compar } \\
\text { ative } \\
\text { growth }\end{array}$ & $\begin{array}{c}\text { Total } \\
\text { accommodation } \\
\text { capacity for } \\
\text { establishments } \\
\text { of tourists } \\
\text { reception with } \\
\text { functions of } \\
\text { tourists } \\
\text { accommodation }\end{array}$ & $\begin{array}{l}\text { Accommoda } \\
\text { tion } \\
\text { capacity for } \\
\text { agro-tourist } \\
\text { boarding } \\
\text { houses }\end{array}$ & $\begin{array}{c}\text { Percen } \\
t, \%\end{array}$ & $\begin{array}{c}\text { Total } \\
\text { accommodation } \\
\text { capacity for } \\
\text { establishments } \\
\text { of tourists } \\
\text { reception with } \\
\text { functions of } \\
\text { tourists } \\
\text { accommodation }\end{array}$ & $\begin{array}{l}\text { Accommo } \\
\text { dation } \\
\text { capacity } \\
\text { for agro- } \\
\text { tourist } \\
\text { boarding } \\
\text { houses }\end{array}$ & $\begin{array}{c}\text { Percent, } \\
\%\end{array}$ \\
\hline 1. & Year & \multicolumn{3}{|c|}{ Romania } & \multicolumn{3}{|c|}{ Latvia } \\
\hline 2. & 2009 & 303486 & 19783 & 6.5 & 32496 & 12113 & 37.3 \\
\hline 3. & 2010 & 311698 & 20208 & 6.5 & 34657 & 12717 & 36.7 \\
\hline 4. & 2011 & 278503 & 20683 & 7.4 & 35745 & 14195 & 39.7 \\
\hline 5. & 2012 & 301109 & 27453 & 9.1 & 36901 & 15134 & 42.01 \\
\hline 6. & 2013 & 305707 & 28755 & 9.4 & 32311 & 11131 & 34.4 \\
\hline 7. & 2014 & 311288 & 30480 & 9.8 & 33459 & 11460 & 34.3 \\
\hline 8. & 2015 & 328313 & 35188 & 10.7 & 34420 & 10311 & 29.95 \\
\hline 9. & 2016 & 328888 & 37394 & 11.4 & 37453 & 12177 & 32.5 \\
\hline 10. & 2017 & 343720 & 44499 & 12.94 & 40824 & 15479 & 37.9 \\
\hline 11. & \multicolumn{7}{|c|}{ Increase of accommodation capacity in agro-tourist boarding houses } \\
\hline 12. & \multicolumn{4}{|c|}{$6.4 \%$ percentage points } & \multicolumn{3}{|c|}{$0.6 \%$ percentage points } \\
\hline
\end{tabular}

Source: author's calculations based on The National Statistics Institute, Tourism of Romania - statistical summary 2009 - 2018; CSB of Latvia 2009 - 2017

In $2017,12.94 \%$ in Romania and $38.0 \%$ in Latvia of the total accommodation capacity were represented by the agro-tourist boarding houses and their number has increased compared to 2009 .

Various development strategies have been developed over time in Romania, which concerned also the agro tourism field, such as certain actions provided in the National Tourism Development Master Plan 2007-2026, and to be more specific, we can mention, Action 35, which requires the regional inspectors of the National Tourism Authority to encourage and facilitate the formation of the destination of rural areas; Action 70, which requires the National Tourism Authority to collect and publish data on traditional festivals and events and to work with NGOs to promote niche products and activities in rural areas; and Action 77a, which requires the National Tourism Authority to set up advertising campaigns with organizers and associations responsible for rural activities, focusing on groups of great interest (Foris et al., 2018). We also find actions aimed at agri-tourism in the Strategy for Ecotourism Development in Romania, 2009 (National Institute of Ecotourism Development in Romania, 2009), such as for example the simplification of the procedure for issuing the Fire Prevention and Fire Extinguishing permit and the Sanitary - Veterinary permit.

\section{Conclusions, proposals, recommendations}

1) During the period 2009 - 2017, agritourism has experienced a real development in Romania and also in Latvia. In Romania, the continuous development of the agro-tourism units is noticed, this resulting in an increase in the number of arrivals both internally and internationally. The development of agri-tourism was based largely on the non-reimbursable financial support granted to entrepreneurs through the European programs for rural development. 
2) In Latvia, just like in Romania, an important role is played by the maintenance of viability of rural areas, thereby providing decent living conditions to rural residents as well. Economic diversification could contribute to it, and tourism is one of the options. According to statistical data, the number of agro-tourist boarding houses increased in Latvia. The numbers of visitors both residents and foreigners - rose as well. Although these processes are taking place more rapidly in Romania than in Latvia, they confirm the importance of tourism as a socio-economic and cultural activity in Latvia.

\section{Bibliography}

1. Autoritatea de Management pentru PNDR (Managing Authority for PNDR) (2013). Analiza socio-economica in perspectiva dezvoltarii rurale 2014-2020 (Socio-economic analysis in the perspective of rural development 2014-2020), p.1.

2. Canja C. M. (2010). Role of Education in Oenotourism Development, International Conference Bioatlas, Brasov, May 2010, p.164.

3. Dorobantu, M. R., Nistoreanu P. (2012). Rural Tourism and Ecotourism- the Main Priorities in Sustainable Development, Orientations of Rural Local Communities in Romania, Economy Transdisciplinarity Cognition, Vol. XV, Issue1, p.3.

4. Caratus Stanciu M. (2017). Agrotourism and Rural Tourism the Way of Sustainable Development in Rural Areas of Sibiu County - Romania, Oltenia. Studii si comunicari. Stiintele Naturii. Tom. 33, No. 2, p.1.

5. Foris D., Comanescu I.S., Foris T. (2018). Trends in Romanian Agritourism in the Context of Sustainable Tourism Development, Proceedings of the 2018 International Scientific Conference 'Economic Sciences for Agribusiness and Rural Economy' No 1, Warsaw, 7-8 June 2018, pp. 81-86.

6. Institutul National de Cercetare-Dezvoltare in Turism - INCDT (National Institute for Research and Development in Tourism - INCDT) (2009). Strategia nationala de dezvoltare a ecoturismului in Romania (Strategy of Ecotourism Development in Romania). p.37.

7. Institutul National de Statistica (The National Statistics Institute) (2018). Turismul Romaniei - breviar statistic (Tourism of Romania - statistical summary), 2009-2018.

8. Jeroscenkova, L. (2016). The Use of Cultural Heritage for the Development of Rural Tourism. Latvia University of Agriculture. Jelgava, p. 124.

9. Kruzmetra, M., Rivza, B., Foris, D. (2018). Modernization of the Demand and Supply Sides for Gastronomic Cultural Heritage. Management Theory and Studies for Rural Business and Infrastructure Development Vol. 40(3), pp. 337-347.

10. Liscova, A. (2011). Farm diversification opportunities for Zemgale planning region farms. Latvia University of Agriculture. Jelgava, $99 \mathrm{p}$.

11. Ministerul Dezvoltarii Regionale si Administratiei Publice (Ministry of Regional Development and Public Administration) (2007). Master Planul pentru Dezvoltarea Turismului National (Master Plan for National Tourism Development), 2007, p. 144.

12. Nistoreanu, P. (2007). Aprecieri asupra fenomenului turistic rural (An appreciation of the rural tourism phenomenon). Revista de turism nr.3. p.17.

13. Order no. 65 of June 10, 2013 for the approval of the Methodological Norms regarding the issuance of certificates of classification of tourist reception structures with functions of accommodation and public food, of licenses and tourism patents (2013). Annex 1.5. Published in the Official Gazette no. 353 of June 142013.

14. PNDR (2012). Programul National de Dezvoltare Rurala 2007-2014 (National Rural Development Program 2007-2014). Retrieved: https://www.fonduri-ue.ro/pndr-2007. Access: 28.06.2019.

15. PNDR (2017). Programul National de Dezvoltare Rurala 2014-2020 (National Rural Development Program 2014-2020), Ghidul Solicitantului- Submasura 6.2-"Sprijin pentru inființarea de activitati neagricole in zone rurale" (Applicant's Guide - Sub-measure 6.2- "Support for setting up non-agricultural activities in rural areas"), p.3.

16. Sumovoschi D.C., Moraru R.A. (2015). Factori motivationali in agroturism (Motivational factors in agrotourism). Turismul rural romanesc in contextul dezvoltarii durabile. Actualitate si perspective, vol XXXVIII, Editura PIM, p. 133.

17. Statistical Bureau of Latvia. (Tourism). Retrieved: http://www.csb.gov.lv Access: 13.01.2018.

18. Tourism in Latvia. (2018) Collection of Statistics. CSB of Latvia, p.64. 